\title{
HUBUNGAN DISIPLIN WAKTU DALAM PEMAKAIAN PIL KB KOMBINASI DENGAN KEGAGALAN AKSEPTOR
}

\author{
Fitriana Ikhtiarinawati Fajrin* \\ Lilis Oktaviani**
}

\begin{abstract}
*Dosen Program Studi Diploma III Kebidanan Universitas Islam Lamongan
**Mahasiswa Program Studi Diploma III Kebidanan Universitas Islam Lamongan
\end{abstract}

\begin{abstract}
ABSTRAK
Kegagalan kontrasepsi saat ini masih menjadi fenomena, Pil KB kombinasi tingkat kegagalannya $0,1 \%$ jika diminum setiap hari. Desain penelitian observasional dengan rancang bangun analitik korelasional dengan pendekatan cross sectional. Populasi akseptor pil KB kombinasi sebanyak 45 orang. Sampel 41 orang dengan cara Simple Random Sampling. Instrumen kuesioner dan rekam medik. uji Koefisien korelasi phi dan tingkat signifikasi $(p \leq 0,05)$.

Hasil penelitian menunjukkan bahwa hampir seluruh akseptor tidak mengalami kegagalan yaitu $82.9 \%$ dan disiplin waktu dalam pemakaian pil $\mathrm{KB}$ kombinasi yaitu $85.4 \%$. sedangkan akseptor yang tidak disiplin waktu dan mengalami kegagalan yaitu 83,3\%. Tingkat kemaknaan sebesar $p=0,000$ dan diperoleh hasil $\mathrm{r} \varnothing=0,729$. Kesimpulan ada hubungan disiplin waktu dalam pemakaian pil KB kombinasi dengan kegagalan akseptor pil KB kombinasi. Maka konseling adekuat tentang cara pemakaian pil KB kombinasi dapat menurunkan angka kegagalan pil KB kombinasi.
\end{abstract}

Kata kunci : Kegagalan, Disiplin, Pil KB Kombinasi

\section{PENDAHULUAN}

Program Keluarga Berencana (KB) bertujuan untuk mengendalikan pertumbuhan jumlah penduduk di Indonesia. Tingginya angka kegagalan tersebut akibat beberapa masalah, yang pertama adalah kurangnya pengetahuan akseptor pil KB kombinasi tentang cara pemakaian pil KB kombinasi, bahwa pil harus diminum setiap hari dan pada jam yang sama. Sering kali akseptor pil KB kombinasi membeli pil KB kombinasi sendiri di tokotoko atau apotik sehingga kadang tidak mendapatkan informasi adekuat terkait pemakaian pil $\mathrm{KB}$ kombinasi dan hanya mendapat informasi sekilas dari dalam kemasan. Bahkan dari hasil studi pendahuluan yang dilakukan di puskesmas maduran, akseptor lebih banyak mendapat pengetahuan dari tetangga daripada dari petugas kesehatan terkait pemakaian pil KB kombinasi. Akseptor juga tidak mengetahui beberapa dari obat antibiotik dan obat anti kejang bisa menurunkan bahkan menghilangkan efektivitas pil. (Saifudin, 2002)

Sampai saat ini tindakan pemerintah untuk menekan angka kegagalan dengan cara meningkatkan komunikasi konseling pada akseptor pil KB kombinasi terkait pemakaian sedangkan untuk menanggulangi 
ketidak disiplinan akseptor dalam meminum pil KB kombinasi beberapa merk dagang diluar pemerintah menawarkan stiker yang mengajak suami untuk turut mengingatkan istrinya untuk meminum pil KB kombinasi setiap hari. (Hanafi, 2004)

\section{TUJUAN PENELITIAN}

Menganalisis hubungan disiplin waktu dalam pemakaian pil KB kombinasi dengan kegagalan akseptor.

\section{TINJAUAN PUSTAKA}

\section{Konsep Dasar Disiplin}

Disiplin berasal dari bahasa latin Discere yang berarti belajar. Dari kata ini timbul kata Disciplina yang berarti pengajaran atau pelatihan. Dan sekarang kata disiplin mengalami perkembangan makna dalam beberapa pengertian. Pertama, disiplin diartikan sebagai kepatuhan terhadap peratuaran atau tunduk pada pengawasan, dan pengendalian. Kedua disiplin sebagai latihan yang bertujuan mengembangkan diri agar dapat berperilaku tertib. secara umum disiplin adalah taat kepada hukum dan peraturan yang berlaku. (Joko, 2010)

\section{Pil KB Kombinasi}

Pil KB Kombinasi adalah pil kontrasepsi berisi estrogen maupun progesteron (progestagen, gestagen). Dosis estrogen ada yang 0,$05 ; 0,08$ dan $0,1 \mathrm{mg}$ pertablet. Sedangkan dosis dan jenis progesteronnya bervariasi dari masing-masing pabrik pembuatnya. (Saifuddin, 2002)

Waktu Mulai Menggunakan Pil Kombinasi
1) Setiap saat selagi haid, untuk menyakinkan kalau perempuan itu tidak hamil

2) Hari pertama sampai hari ke 7 siklus haid

3) Boleh menggunakan pada hari ke 8 tetapi perlu menggunakan meode kontrasepsi yang lain mulai hari ke-8 sampai hari ke 14 atau tidak melakukan hubungan seksual sampai perempuan telah menghabiskan paket pil tersebut.

4) Setelah melahirkan :

(1) Setelah 6 bulan pemberian ASI ekslusif

(2) Setelah 3 bulan dan tidak menyusui

(3) Pasca keguguran (segera atau dalam waktu 7 hari)

(4) Bila berhenti menggunakan kontrasepsi injeksi dan ingin menggantikan dengan pil kombinasi, pil dapat segera diberikan tanpa perlu menunggu haid. (Saifuddin, 2002)

Cara Mempergunakan Pil KB Kombinasi Adalah Sebagai Berikut :

1) Sebaiknya pil diminum setiap hari, lebih baik pada saat yang sama setiap hari

2) Pil yang pertama dimulai pada hari pertama sampai hari ke-7 siklus haid.

3) Sangat dianjurkan penggunaanya pada hari pertama haid.

4) Beberapa paket pil mempunyai 28 pil, yang lain 21 pil. Bila paket 28 pil habis, sebaiknya anda mulai minum pil dari paket yang baru. Bila paket 21 habis, sebaiknya tunggu 1 minggu baru kemudian mulai minum pil dari paket yang baru.

5) Bila muntah dalam waktu 2 jam setelah menggunakan pil, ambillah pil yang lain atau 
menggunakan metode kontrasepsi yang lain.

6) Bila terjadi muntah hebat, atau diare lebih dari 24 jam, maka bila keadaan memungkinkan dan tidak memperburuk keadaan Anda, pil dapat diteruskan.

7) Bila muntah dan diare berlangsung sampai 2 hari atau lebih, cara penggunaan pil mengikuti cara menggunakan pil lupa.

8) Bila lupa minum 1 pil (hari 121), sebaiknya minum pil tersebut segera setelah ingat walaupun harus minum 2 pil pada hari yang sama. Tidak perlu meggunakan metode kontrasepsi yang lain. Bila lupa 2 pil atau lebih (hari 1-21), sebaiknya minum 2 pil setiap hari sampai sesuai skedul yang ditetapkan. Juga sebaiknya menggunakan metode kontrasepsi yang lain atau tidak melakukan hubungan seksual sampai telah menghsbiskan paket pil tersebut.

9) Bila tidak haid, perlu segera ke klinik untuk tes kehamilan. Beberapa jenis obat dapat mengurangi efektivitas pil, seperti rifampisin, fenitoin (Dilantin), barbiturat, griseofulvin, trisiklik antidepresan, ampisilin dan penisilin, tetrasiklin. Klien yang memakai obat-obatan di atas untuk jangka panjang sebaiknya menggunakan pil kombinasi dengan dosis $50 \quad \mu \mathrm{g}$ atau dianjurkan menggunakan metode kontrasepsi yang lain. (Saifuddin, 2002).

\section{Konsep Kegagalan Akseptor Pil KB Kombinasi}

Kegagalan

adalah

ketidakberhasilan. Tidak berhasil berarti pula tidak tercapainya target yang telah ditetapkan. Karena adanya target untuk dapat dipakai sebagai pengukur suatu keberhasilan. Maka dari itu selalu ada kriteria-kriteria sebagai parameter guna menentukan, apakah suatu target telah tercapai atau belum tercapai. Dari logika ini dapatlah ditarik suatu pengertian, kegagalan adalah tidak tercapainya target yang telah ditetapkan. (Joko, 2010).

Akseptor KB adalah anggota masyarakat yang mengikuti gerakan KB dengan melaksanakan dan penggunaan alat kontrasepsi. Akseptor KB menurut sasarannya terbagi menjadi tiga fase yaitu fase menunda atau mencegah kehamilan, fase penjarangan kehamilan dan fase menghentikan atau mengakhiri kehamilan atau kesuburan. Akseptor KB lebih disarankan untuk Pasangan Usia Subur (PUS) dengan menggunakan alat kontrasepsi. Karena pada pasangan usia subur inilah yang lebih berpeluang besar untuk menghasilkan keturunan dan dapat meningkatkan angka kelahiran.

\section{Konsep Disiplin Waktu dalam Pemakaian Pil KB Kombinasi dengan Kegagalan Akseptor Pil KB Kombinsi}

Dasar dari pil oral adalah meniru proses-proses alamiah. Pil oral akan menggantikan produksi normal esterogen dan progesterone oleh ovarium. Pil oral akan menekan hormon ovarium selama siklus haid yang normal, sehingga juga menekan releasing-factor di otak dan akhirnya mencegah ovulasi. Pil oral harus diminum tiap hari agar efektif karena mereka dimetabolisir dalam 24 jam. Bila akseptor lupa 1 atau 2 tablet, maka mungkin terjadi peninggian hormon-hormon alamiah, yang 
selanjutnya mengakibatkan ovum menjadi matang lalu dilepaskan.

(Hanafi, 2010)

\section{Konsep Dasar Prilaku}

Dari segi biologis, perilaku adalah suatu kegiatan atau aktifitas organisme (makhluk hidup) yang bersangkutan. Oleh sebab itu, dari sudut pandang biologis semua makhluk hidup mulai dari tumbuhtumbuhan, binatang sampai dengan manusia itu berperilaku, karena mereka mempunyai aktifitas masingmasing. Sehingga yang dimaksud perilaku manusia, pada hakikatnya adalah tindakan atau aktifitas manusia dari manusia itu sendiri yang mempunyai bentangan yang sangat luas, antara lain mencakup : berjalan, berbicara, bereaksi, berpakaian dan sebagainya. Dari uraian diatas dapat disimpulkan bahwa yang dimaksud perilaku (manusia) adalah semua kegiatan atau aktifitas manusia, baik yang dapat diamati secara langsung maupun tidak secara langsung. (Soekidjo Notoatmodjo, 2007 : 131132).

\section{HIPOTESIS}

Ada hubungan Disiplin Waktu Dalam Pemakaian Pil KB Kombinasi Dengan Kegagalan Akseptor Pil KB Kombinasi.

\section{METODE PENELITIAN}

Jenis penelitian observasional dengan rancang bangun analitik korelasional dengan cross sectional. Populasi adalah Seluruh Akseptor pil KB Kombinasi dengan jumlah 46 orang, jumlah sampel 41 Akseptor pil KB Kombinasi dengan cara Simple Random Sampling. Instrumen penelitian yang digunakan adalah kuesioner dan formulir rekam medik. analisis uji Koefisien kolerasi phi.

\section{HASIL PENELITIAN}

Hasil uji Koefisien korelasi $P h i$ yang mana dengan tingkat kemaknaan $p=0,000$ antara disiplin waktu dalam pemakaian pil KB kombinasi dengan kegagalan akseptor pil KB kombinasi, diperoleh hasil $\mathrm{r}_{\emptyset}=0,729, p=0,000$ dimana $p$ $\leq 0,05$ sehingga $\mathrm{H}_{0}$ ditolak artinya ada hubungan disiplin waktu dalam pemakaian pil KB kombinasi dengan kegagalan akseptor pil KB kombinasi.

\section{PEMBAHASAN}

\section{Disiplin Waktu Dalam Pemakaian Pil KB Kombinasi}

Hasil penelitian umur
akseptor hampir sebagian besar masih berkisar antara 26-33 tahun, yang mana masih belum matang secara emosional, sehingga dalam pemakaian pil KB kombinasi cenderung untuk mengabaikan dalam hal kedisiplinan waktu.

Jumlah paritas atau jumlah anak pada distribusi akseptor menunjukkan hampir sebagian besar akseptor telah memiliki 2 anak $(36,6 \%)$, dalam hal ini paritas mempengaruhi tingkat kedisiplinan karena semakin sedikit jumlah paritas maka akseptor akan menganggap bahwa memiliki 1 atau 2 orang anak lagi tidaklah masalah jika mereka mengalami kegagalan.

Pendidikan terakhir akseptor yang di telah dilampaui oleh akseptor ditemukan rata-rata telah melampaui batas minimal pendidikan formal yaitu 9 tahun/sampai tingkat SMP, meskipun hanya 2 orang yang mampu melampaui tingkat perguruan tinggi. dengan tingkat pendidikan akseptor yang lebih baik ini, akan 
dapat menggunakan pil KB kombinasi secara disiplin, namun yang terjadi dilapangan, ternyata dengan semakin meningkatnya tingkat pendidikan akseptor dan pengetahuan akseptor bahwa pil KB kombinasi harus diminum setiap hari. Pendapat tersebut sesuai dengan hasil penelitian menunjukkan bahwa hampir seluruh akseptor disiplin waktu dalam pemakaian pil KB kombinasi yaitu 35 akseptor (85.4\%).

\section{Kegagalan akseptor pil KB kombinasi}

Pada saat ini kontrasepsi adalah sebuah kebutuhan bagi masyarakat, bukan lagi sebuah hal yang dibutuhkan oleh pemerintah sebagai pendorong program KB. Sejak beberapa tahun yang lalu telah berkembang isu dalam masyarakat bahwa memiliki anak banyak hanya akan membawa beban dalam keluarga, terlalu banyak anak akan semakin banyak biaya kehidupan yang di keluarkan. Isu tersebut sekaligus menggantikan isu banyak anak banyak rezeki. Sebagian orang yang lain berpandangan bahwa dengan memakai alat kontrasepsi, akan menunda kehamilan adalah hal yang sangat penting / dibutuhkan, karena akan memberikan keleluasaan keluarga untuk mencurahkan kasih sayang, kebutuhan materi dan waktu mereka secara berkualitas kepada anak mereka yang sedikit, dibandingkan jika telah memiliki anak yang banyak karena harus berbagi dengan banyak anaknya. Dengan begitu pendidikan dan kasih sayang kepada anak akan diberikan pula secara maksimal, sehingga akan menghasilkan individu atau keturunan yang berkualitas.

Kegagalan akseptor pil KB kombinasi yaitu terjadinya konsepsi pada akseptor pil KB kombinasi. Cara kerja pil KB kombinasi meniru proses-proses alamiah dalam tubuh manusia. Kegagalan pada akseptor dapat terjadi karena akseptor hampir sebagian besar usia 23-26 tahun, usia matang secara seksual dan sangat subur.

Dengan semangat melakukan aktivitas ini akseptor cenderung akan lebih banyak lupa untuk minum pil KB karena terlalu banyak aktivitas yang dilakukan sehingga kelelahan dan lupa untuk meminum pil $\mathrm{KB}$ kombinasi tepat pada waktunya. Padahal pil KB kombinasi harus diminum tiap hari agar efektif karena hanya dapat dimetabolisir dalam tubuh selama 24 jam. Bila akseptor lupa 1 atau 2 tablet, maka mungkin terjadi peninggian hormon-hormon alamiah, Pendapat diatas sesuai dengan "Dasar dari pil oral adalah meniru proses-proses alamiah. Pil oral akan menggantikan produksi normal esterogen dan progesterone oleh ovarium. Pil oral akan menekan hormon ovarium selama siklus haid yang normal, sehingga juga menekan releasing-factor di otak dan akhirnya mencegah ovulasi. Pil oral harus diminum tiap hari agar efektif karena mereka dimetabolisir dalam 24 jam. Bila akseptor lupa 1 atau 2 tablet, maka mungkin terjadi peninggian hormon-hormon alamiah, yang selanjutnya mengakibatkan ovum menjadi matang lalu dilepaskan".

Pendapat tersebut sekaligus menjawab dari hasil penelitian menunjukkan bahwa hampir seluruh akseptor pil KB kombinasi yang menggunakan pil KB kombinasi dengan tidak disiplin dan mengalami kegagalan yaitu 5 akseptor (83.3\%) sedangkan hampir seluruh akseptor pil KB kombinasi yang menggunakan pil KB kombinasi 
dengan tidak disiplin dan tidak mengalami kegagalan yaitu 2 akseptor (5.7\%). Oleh karena itu, jika disiplin waktu dalam pemakaian pil KB kombinasi maka kegagalan pil KB kombinasi akan dapat terhindarkan.

\section{SIMPULAN DAN SARAN}

\section{Simpulan}

Ada hubungan disiplin waktu dalam pemakaian pil $\mathrm{KB}$ kombinasi dengan kegagalan akseptor pil KB kombinasi.

\section{Saran}

Pelatihan konseling secara adekuat tentang pentingnya disiplin waktu dalam pemakaian pil $\mathrm{KB}$, untuk meningkatkan kemampuan tenaga kesehatan yang profesional.

\section{DAFTAR PUSTAKA}

Baziad, Ali. 2000. Kontrasepsi Hormonal. Jakarta: Bina Nusantara Sarwono Prawiroharjo.

Hartanto, Hanafi. 2004. Keluarga Berencana dan Kontrasepsi. Jakarta : Pustaka Sinar Harapan.

Iskandar, Joko. 2010. Konsep Perilaku Kesehatan. Http://www.arsipindoscript.co.cc/2010_03_01_a rchive.html dan diakses pada tanggal 29 Mei 2010.

Notoatmodjo, Soekidjo. 2007. Kesehatan Masyarakat Ilmu dan Seni. Jakarta : Rineka Cipta.

Saifuddin, Abdul Bari dkk. 2002. Pelayanan Kontrasepsi. Jakarta
:Yayasan Bina Pustaka Sarwono Prawirohardjo 